\title{
Branched-chain amino acid and lysine deficiencies exert different effects on mammary translational regulation
}

\author{
John Doelman, ${ }^{* 1}$ Julie J. M. Kim, $†$ Michelle Carson, ${ }^{*}$ John A. Metcalf, ${ }^{*}$ and John P. Cant† \\ *Nutreco Canada Agresearch, Guelph, Ontario, N1G 4T2 Canada \\ †Department of Animal BioSciences, University of Guelph, Guelph, Ontario, N1G 2W1 Canada
}

\begin{abstract}
Deficiencies and imbalances of specific group II essential amino acids (EAA) were created in lactating cows by an infusion subtraction protocol to explore effects on milk production and abundance and phosphorylation state of regulators of mRNA translation in the mammary glands. Five lactating cows on a diet of $11.2 \%$ crude protein were infused abomasally for $5 \mathrm{~d}$ with saline, $563 \mathrm{~g} / \mathrm{d}$ of a complete EAA mix, or EAA mixes without the branched-chain amino acids $(\mathrm{BCAA})$, Leu, or Lys in a $5 \times 5$ Latin square design. Milk protein yield was stimulated by EAA infusion and returned to saline levels upon subtraction of BCAA, Leu, or Lys. Mammary abundance of phosphorylated S6K1 was measured as an indicator of mammalian target of rapamycin complex 1 (mTORC1) activity and was found not to be affected by the complete EAA mix but was increased by the mixture lacking Lys. Total S6K1 abundances in mammary tissue were elevated by complete and BCAA-lacking infusions. All of the EAA treatments except the one lacking BCAA upregulated mammary $\operatorname{eIF} 2 \mathrm{~B} \varepsilon$ and $\operatorname{eIF} 2 \alpha$ abundances, which is stimulatory to global mRNA translation. Phosphorylation state of eIF2B $\varepsilon$ tended to decrease when complete or Lys-lacking EAA mixtures were infused. Phosphorylation state of eIF $2 \alpha$ was not affected by treatment. We detected a correlation of 0.62 between phosphorylation state of S6K1 and total eIF2B $\varepsilon$ abundance, and a correlation of 0.58 between phosphorylation state of S6K1 and total eIF $2 \alpha$ abundance, suggesting that mTORC1 activation may have upregulated $\operatorname{eIF} 2 \mathrm{~B} \varepsilon$ and $\operatorname{eIF} 2 \alpha$ expression. Despite maintenance of mammary eIF2B $\varepsilon$ and eIF $2 \alpha$ abundances during Leu and Lys deficiencies, milk protein yield declined, suggesting that other factors are responsible for mediating effects of Lys and Leu. A deficiency of all 3 BCAA may impair milk protein yield through deactivation of mTORC1-mediated upregulation of $\mathrm{eIF} 2 \mathrm{~B} \varepsilon$ and $\mathrm{eIF} 2 \alpha$ abundances.
\end{abstract}

Received May 14, 2015.

Accepted July 17, 2015

${ }^{1}$ Corresponding author: john.doelman@nutreco.ca
Key words: mammary gland, milk protein, translation, amino acid, branched-chain amino acids

\section{INTRODUCTION}

The dietary $\mathrm{N}$ consumed by lactating dairy cows that is not captured in milk or body tissues is ultimately lost into the environment. Factors that stimulate milk protein yield can reduce these environmental losses and improve the economic efficiency of milk production. Essential amino acids are stimulatory to milk protein synthesis but individual EAA differ in the size of the effect they exert on milk protein yield. Increasing postruminal supplies of Met, Lys, or His has caused milk protein yield to increase to varying degrees (Schwab et al., 1976; Vanhatalo et al., 1999; Robinson, 2010). Due to the ruminal degradation and synthesis of EAA, a portion of the variation in response to supplementation of each of these EAA may be related to the availability of other EAA for protein synthesis, such that the response to Met may be limited by Lys (Schwab et al., 1976), for example. A subtraction protocol, where single EAA are subtracted from a complete supplement instead of added to a basal diet, was devised by Storm and Ørskov (1984) for ruminants and implemented in lactating ruminants (Fraser et al., 1991; Kim et al., 1999; Bequette et al., 2000) to remove the uncertainty regarding purported limitations from EAA other than the one under investigation. Subtraction of more than one-third of the metabolizable Met, His, or Phe supply negatively affects milk protein yield (Fraser et al., 1991; Kim et al., 1999; Weekes et al., 2006; Doelman et al., 2015). These group I EAA are used by milk secretory cells for protein synthesis only and are not catabolized, whereas other EAA are catabolized in the mammary glands to provide amino groups for NEAA synthesis (Mepham, 1982). Members of this second category of EAA are considered group II AA (Mepham, 1982) and include Lys, Arg, Thr, and the branched-chain AA (BCAA) Leu, Ile, and Val. Subtraction of more than one-third of the metabolizable Lys supply to cows decreases milk protein yield (Weekes et al., 2006; Lapierre et al., 2009), whereas subtraction of a similar fraction of 
the Arg supply has had no effect (Doepel and Lapierre, 2011; Haque et al., 2013). Branched-chain amino acid subtraction produces equivocal responses. Subtraction of $40 \mathrm{~g} / \mathrm{d}$ of Leu from $135 \mathrm{~g} / \mathrm{d}$ of metabolizable Leu, or $23 \mathrm{~g} / \mathrm{d}$ of Val from 111 of $\mathrm{g} / \mathrm{d}$ metabolizable Val decreased milk protein yield (Rulquin and Pisulewski, 2006; Haque et al., 2013), whereas subtraction of 19 $\mathrm{g} / \mathrm{d}$ of Ile from $99 \mathrm{~g} / \mathrm{d}$ of metabolizable Ile had no effect (Haque et al., 2013). Despite the responses to Leu and Val, subtraction of $160 \mathrm{~g} / \mathrm{d}$ of all 3 BCAA from $411 \mathrm{~g} / \mathrm{d}$ of BCAA had no effect on milk yield or composition (Weekes et al., 2006).

Different responses to BCAA could be related to their potency as stimulators of protein synthesis via mammalian target of rapamycin complex 1 (mTORC1). The cellular global rate of mRNA translation is controlled by mTORC1 through phosphorylation of ribosomal S6 kinase 1 (S6K1) and eukaryotic initiation factor (eIF) 4E-binding protein 1 (4EBP1) in response to stimulation by protein kinase B (Akt) and AA (Shimobayashi and Hall, 2014). The AMP-activated protein kinase (AMPK) inhibits mTORC1 to slow down protein synthesis (Gwinn et al., 2008). By these mechanisms, mTORC1 integrates intracellular well-being with external hormonal signals to decide upon an appropriate rate of global protein synthesis. The postprandial increases in muscle and liver protein synthesis in nonruminants have been attributed to mTORC1 activation (Kimball et al., 2000). Recently, we reported that infusions of a complete EAA mix or mixes lacking His, Met, or Phe stimulated mammary mTORC1 and increased abundance of the eIF2B enzyme responsible for preparing eIF2 to engage in initiation of mRNA translation (Doelman et al., 2015). This increase in eIF2B may have been due to an mTORC1-mediated stimulation of translation of eIF2B mRNA into protein (Kubica et al., 2008). The BCAA, particularly Leu, are potent stimulators of mTORC1 in muscle, liver, and mammary cells (Anthony et al., 2000; Moshel et al., 2006; Toerien et al., 2010; Appuhamy et al., 2012; Suryawan et al., 2012) so the subtraction of BCAA may produce a different mammary mTORC1 response than subtraction of other EAA. Although abomasal infusion of mixtures of all EAA except His, Met, or Phe activated mammary mTORC1, only a complete mix of all EAA stimulated milk protein yield (Doelman et al., 2015), suggesting that low plasma concentrations of the EAA missing from imbalanced infusates interfered with the milk protein response. The proposed mechanism by which single EAA deficiencies interfere with protein synthesis is through phosphorylation of the $\alpha$ subunit of eIF2, which then becomes an inhibitor of eIF2B (Proud, 2005). However, abomasal infusates lacking His, Met, or Phe did not affect phosphorylation of mammary eIF2 $\alpha$ (Doelman et al., 2015).

The purpose of the current experiment was to evaluate effects of deficiencies and imbalances of group II EAA on mammary S6K1, eIF2B $\varepsilon$, and eIF2 $\alpha$ abundances and milk component yields in lactating cows. Cows were fed a low-protein diet as a negative control and infused with all 10 EAA as a positive control. In an attempt to create deficiencies of group II EAA, Lys, Leu, or all 3 BCAA were subtracted from the positive control. Responses to infusion of these incomplete EAA mixtures compared with the negative control were considered effects of AA imbalances.

\section{MATERIALS AND METHODS}

\section{Experimental Protocol and Sampling}

All animal procedures were approved by the Animal Care and Use Committee at Nutreco Canada Agresearch, adhering to guidelines set forth by the Canadian Council on Animal Care (2009). Five multiparous (2.2 \pm 0.4 lactations) rumen-cannulated, lactating dairy cows producing an average of $31.1 \mathrm{~kg} / \mathrm{d}$ at $105 \pm$ $12 \mathrm{~d}$ of lactation and $631 \pm 47 \mathrm{~kg}$ of BW were randomly assigned to a $5 \times 5$ Latin square design, where each period consisted of $5 \mathrm{~d}$ of infusion followed by $2 \mathrm{~d}$ of rest. Cows were fed a TMR to provide an $\mathrm{NE}_{\mathrm{L}}$ of 6.57 $\mathrm{MJ} / \mathrm{kg} \mathrm{DM}$ and $11.2 \% \mathrm{CP}$ (Table 1) to meet $100 \%$ and $70 \%$ of net energy and MP requirements, respectively (NRC, 2001). Production targets were $32 \mathrm{~kg} / \mathrm{d}$ of milk yield containing 1,024 $\mathrm{g}$ of fat and $896 \mathrm{~g}$ of protein. Cows were acclimated through ad libitum intake of the diet for $14 \mathrm{~d}$ before start of the experiment. They were fed once daily at $0700 \mathrm{~h}$ for the duration of the experiment at a fixed amount equal to the daily average during the last $7 \mathrm{~d}$ of the acclimation period. Cows were weighed $2 \mathrm{~d}$ before the first period and at the end of each period. Feed refusals were measured daily and feed samples were taken on a weekly basis, stored at $-20^{\circ} \mathrm{C}$, pooled, and subsampled for proximate analysis. Silages were monitored weekly for DM content and the TMR mix was adjusted accordingly.

Infusion lines were inserted into the abomasum via rumen cannulas $1 \mathrm{~d}$ before the first experimental period and checked daily for patency. A Watson-Marlow 205U/CA multi-channel peristaltic pump (Wilmington, MA) was used to abomasally infuse treatments of saline (SAL), all 10 EAA (EAA), and EAA without Lys (Lys-), Leu (Leu-), or the branched-chain AA (Ile, Leu, and Val; BCAA-). Amino acids were infused at the following rates $(\mathrm{g} / \mathrm{h})$, equivalent to their secretion in $1,000 \mathrm{~g} / \mathrm{d}$ of casein according to Metcalf et al. (1996) 
Table 1. Ingredient and chemical composition (\% of DM, unless otherwise noted) of feedstuffs and TMR

\begin{tabular}{lc}
\hline Component & Content \\
\hline Ingredient & \\
Corn silage & 38.2 \\
Alfalfa silage & 14.4 \\
Mixed hay & 3.7 \\
Wheat straw & 7.3 \\
Dairy supplement ${ }^{1}$ & 36.4 \\
Nutrient & \\
$\mathrm{CP}$ & 11.2 \\
$\mathrm{NDF}$ & 31.9 \\
$\mathrm{ADF}$ & 20.6 \\
$\mathrm{NE}$ & $(\mathrm{MJ} / \mathrm{kg})$ \\
$\mathrm{Ca}$ & 6.57 \\
$\mathrm{P}$ & 0.69 \\
\hline
\end{tabular}

${ }^{1}$ Obtained from Shur-Gain Feed Mill (St. Mary's, ON, Canada) and contained $6.78 \mathrm{MJ} / \mathrm{kg}$ of $\mathrm{NE}_{\mathrm{L}}$ and $12.72 \% \mathrm{CP}$. Supplement consisted of corn $(55.76 \%)$, wheat shorts $(38.14 \%)$, limestone $(2.02 \%)$, salt $(1.31 \%)$, magnesium oxide $(0.55 \%)$, vitamin and mineral premix $(0.30 \%)$, magnesium sulfate $(0.29 \%)$, potassium sulfate $(0.29 \%)$, selenium $(0.14 \%)$, and vitamin $\mathrm{E}(0.01 \%)$.

and estimated to meet $100 \%$ of MP requirements with the basal diet: L-Arg (1.64), L-His (1.34), L-Ile (2.39), L-Val (2.66), L-Leu (3.92), L-Phe (3.92), L-Met (1.14), L-Lys (4.09), L-Thr (1.76), and L-Trp (0.59). The EAA solutions of $10 \mathrm{~L}$ were prepared daily and infused continuously into cows at a rate of approximately 6.95 $\mathrm{mL} / \mathrm{min}(563 \mathrm{~g} / \mathrm{d}$ of EAA).

Cows were milked twice daily at 0600 and $1500 \mathrm{~h}$. Milk was collected, weighed, and sampled separately from the front and rear quarters at each milking. Milk samples were stored at $4^{\circ} \mathrm{C}$ and analyzed within $3 \mathrm{~d}$.

Blood samples were taken on the final day of each period at $1000 \mathrm{~h}$ from a coccygeal vessel into sodium heparin and potassium EDTA Vacutainers (Becton Dickinson, Rutherford, NJ). Samples were centrifuged at $1,500 \times g$ for 20 min and plasma was withdrawn into polypropylene vials and frozen at $-20^{\circ} \mathrm{C}$ until analysis.

On d 5 of each period, approximately $500 \mathrm{mg}$ of mammary tissue was obtained from a randomly selected rear quarter by biopsy (Toerien et al., 2010). Rear quarters selected for biopsy were alternated in successive periods. Each sample was rinsed in saline, blotted dry, frozen in liquid $\mathrm{N}_{2}$, and stored at $-80^{\circ} \mathrm{C}$ until analysis.

\section{Sample Analysis}

Milk samples were analyzed for fat, protein, and lactose contents by infrared spectroscopy (Laboratory Services Division, University of Guelph, Guelph, ON, Canada). Proximate composition of diet samples was determined by near-infrared spectroscopy at a commercial laboratory (Nutreco Canada Inc., St. Hyacinthe, QC, Canada). Plasma samples were analyzed spectrophoto- metrically for glucose, NEFA, and $\beta$-hydroxybutyrate (BHB) as previously described (Weekes et al., 2006). Plasma AA were quantified by reversed-phase UPLC using the AccQ-Tag derivatization method (Waters Chromatography Division, Milford, MA) as described by Boogers et al. (2008).

\section{Gel Electrophoresis and Western Blot Analysis}

Approximately $100 \mathrm{mg}$ of mammary tissue was homogenized with $1 \mathrm{~mL}$ of lysis buffer (1\% Triton X-100, $0.1 \%$ SDS, $50 \mathrm{~m} M$ Tris-HCl pH 7.4, $150 \mathrm{~m} M \mathrm{NaCl}$, and $0.5 \%$ sodium deoxycholate) containing protease and phosphatase inhibitors (Thermo Scientific, Nepean, ON, Canada) for $10 \mathrm{~s}$ before inversion for $1 \mathrm{~h}$ at $4^{\circ} \mathrm{C}$. Lysates were centrifuged at $13,000 \times g$ for $15 \mathrm{~min}$ at $4^{\circ} \mathrm{C}$, and supernatants were extracted and stored at $-20^{\circ} \mathrm{C}$. The concentration of DNA was measured using the Qubit 2.0 Fluorometer (Life Technologies Inc., Burlington, ON, Canada) with the Qubit dsDNA BR Assay.

Western blot analysis of mammary protein abundance was as described previously (Curtis et al., 2014). Briefly, duplicate samples of mammary supernatant were diluted in lysis buffer and sample buffer then boiled at $95^{\circ} \mathrm{C}$ for $5 \mathrm{~min}$. Samples containing 10 to 30 $\mu \mathrm{g}$ of protein were separated by 10 to $12 \%$ SDS-PAGE at $120 \mathrm{~V}$ for approximately $90 \mathrm{~min}$. Proteins were electrotransferred (Bio-Rad Laboratories Inc., Mississauga, ON, Canada) onto polyvinylidene difluoride membranes and were incubated in 5\% skim milk blocking buffer solution for $1 \mathrm{~h}$ at room temperature, followed by three 5 -min washes in Tris-buffered saline-Tween (TBST) buffer. Membranes were incubated for $1 \mathrm{~h}$ at room temperature with rabbit monoclonal antibodies to S6K1 (1:800, Abcam, Cambridge, MA, \#ab9366), phosphorylated S6K1 (pS6K1; Thr389; 1:800, Abcam, \#ab2571), eIF2B $\varepsilon$ (1:1,000, Abcam, \#ab32713), phosphorylated $\mathrm{eIF} 2 \mathrm{~B} \varepsilon$ (peIF2B $\varepsilon$; Ser539; 1:1000, Abcam,

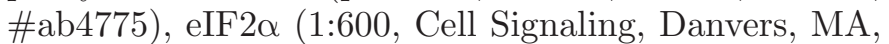
\#3597), phosphorylated eIF2 $\alpha$ (peIF2 $\alpha$; Ser51; 1:1000, Cell Signaling, \#3597S), or $\beta$-actin (1:40000, Abcam, \#ab6276). All antibodies were diluted using 1\% milk TBST buffer. Membranes were washed with TBST buffer and incubated at room temperature for $1 \mathrm{~h}$ with horseradish peroxidase-linked anti-rabbit IgG (1:2000; Cell Signaling, \#7074). Membranes were washed and proteins were visualized by autoradiography using enhanced chemiluminescence (Amersham, Arlington Heights, IL). Images from radiographic film (VWR International, Pittsburgh, PA) were scanned and the integrated density was determined by ImageJ software (http://rbs.info.nih.gov/ij). A common reference sam- 
ple was included on each of 3 gels required to separate all samples. Densities were normalized first to $\beta$-actin density to account for protein loading differences, and then to a normalized reference sample density to account for differences between gels. Phosphorylation states of each protein were determined as the ratio of normalized phosphorylated protein density to normalized total protein density.

\section{Calculations and Statistical Analysis}

Milk production and composition were averaged over the last $2 \mathrm{~d}$ of each period. Phosphorylation states of signaling proteins were natural log-transformed to become normally distributed. Normality was tested with the Shapiro-Wilk test using the Univariate procedure in SAS (SAS Institute Inc., Cary, NC). Variance in each observation $\left(\mathrm{Y}_{\mathrm{ijk}}\right)$ was analyzed using the MIXED procedure in SAS according to the following model:

$$
\mathrm{Y}_{\mathrm{ijk}}=\mu+\operatorname{cow}_{\mathrm{i}}+\operatorname{per}_{\mathrm{j}}+\operatorname{trt}_{\mathrm{k}}+\varepsilon_{\mathrm{ijk}},
$$

where $\mu=$ overall mean; $\mathrm{cow}_{\mathrm{i}}=$ ith random cow effect $(\mathrm{i}=1$ to 5$) ;$ per $_{\mathrm{j}}=\mathrm{jth}$ fixed period effect $(\mathrm{j}=1$ to 5$)$; $\operatorname{trt}_{\mathrm{k}}=\mathrm{kth}$ fixed treatment effect $(\mathrm{k}=1$ to 5$)$; and $\varepsilon_{\mathrm{ijk}}$ $=$ random variation. Treatment means were separated by Tukey's test. Differences were considered significant at $P \leq 0.05$ and tendencies at $0.05<P \leq 0.1$. Milk production and composition data from the front, nonbiopsied mammary glands and the whole udder were each subjected to statistical analysis separately, but treatment effects were not different. The results reported herein are from the front and rear mammary glands combined. To test for carryover of treatment effects from one period to the next, an additional factor representing the treatment applied in the previous period was considered in the ANOVA. No carryover effects were detected $(P>0.23)$.

\section{RESULTS}

\section{Animal Health}

Body weight was not affected by treatment and was maintained within $94 \%$ of pre-study values. Mammary biopsies resulted in a transient decrease in milk yield that recovered within $72 \mathrm{~h}$. All cows remained on trial for the duration and the experiment was completed in 5 periods.

\section{Milk Production and Composition}

Abomasal infusion of the complete EAA mix increased milk protein yield by $153 \mathrm{~g} / \mathrm{d}$ compared with SAL $(P=0.002$; Table 2$)$. Subtraction of BCAA, Leu, or Lys decreased milk protein yield by $123(P=0.028)$, $212(P<0.001)$, or $103(P=0.009) \mathrm{g} / \mathrm{d}$, respectively, compared with EAA. Additionally, BCAA and Leu subtractions decreased milk protein concentrations compared with EAA $(P<0.01)$, whereas Lys - tended to decrease it $(P=0.057)$. Dry matter intake, milk yields, and milk fat and lactose percentages and yields were not affected by treatment $(P>0.247)$.

\section{Plasma Constituents}

Concentrations of glucose, BHB, and NEFA in plasma were not affected by treatment $(P>0.149$; Table 3). Plasma EAA increased 50 to $400 \%$ in concentration with EAA infusion $(P \leq 0.05)$ except for Arg and Ile, which were not significantly affected despite approximately 200\% increases (Table 4). Subtraction of BCAA from the EAA infusate caused Leu and Val concentrations to decrease to levels commensurate with SAL infusion $(P=0.006)$. Subtraction of Leu alone also caused Leu concentration to decrease back to SAL levels $(P=0.006)$, but the other BCAA (Ile and Val) increased close to $200 \%$ in concentration $(P<0.05)$,

Table 2. Performance responses to abomasal infusion of EAA mixtures in lactating dairy cows $(\mathrm{n}=5)^{1}$

\begin{tabular}{|c|c|c|c|c|c|c|c|}
\hline \multirow[b]{2}{*}{ Item } & \multicolumn{5}{|c|}{ Treatment } & \multirow[b]{2}{*}{ SEM } & \multirow[b]{2}{*}{$P$-value } \\
\hline & Saline & EAA & $\mathrm{BCAA}-$ & Leu- & Lys- & & \\
\hline DMI $(\mathrm{kg} / \mathrm{d})$ & 19.1 & 19.4 & 19.4 & 19.0 & 19.0 & 1.1 & 0.927 \\
\hline Milk (kg/d) & 28.6 & 31.5 & 30.8 & 29.1 & 30.6 & 1.1 & 0.247 \\
\hline Fat $(\mathrm{g} / \mathrm{d})$ & 828 & 858 & 858 & 808 & 886 & 98 & 0.665 \\
\hline Protein $(\mathrm{g} / \mathrm{d})$ & $852^{\mathrm{ab}}$ & $1,005^{\mathrm{c}}$ & $882^{\mathrm{ab}}$ & $793^{\mathrm{a}}$ & $902^{\mathrm{b}}$ & 22 & 0.035 \\
\hline Lactose $(\mathrm{g} / \mathrm{d})$ & 1,406 & 1,533 & 1,527 & 1,430 & 1,471 & 80 & 0.733 \\
\hline Fat $(\%)$ & 2.90 & 2.69 & 2.85 & 2.93 & 2.91 & 0.35 & 0.714 \\
\hline Protein (\%) & $3.00^{\mathrm{ab}}$ & $3.20^{\mathrm{a}}$ & $2.91^{\mathrm{b}}$ & $2.91^{\mathrm{b}}$ & $2.98^{\mathrm{a}}$ & 0.09 & 0.013 \\
\hline Lactose (\%) & 4.93 & 4.86 & 4.92 & 4.89 & 4.81 & 0.13 & 0.603 \\
\hline
\end{tabular}

${ }^{a-c}$ Means in a row with different superscripts are significantly different, $P \leq 0.05$.

${ }^{1}$ Data are least squares means. Treatments were $5 \mathrm{~d}$ of abomasal infusion with saline, EAA, EAA less branchedchain amino acids (BCAA; BCAA-), EAA less Leu (Leu-), or EAA less Lys (Lys-). 
Table 3. Plasma concentrations of metabolites in lactating dairy cows $(n=5)$ abomasally infused with EAA mixtures ${ }^{1}$

\begin{tabular}{lccccccc}
\hline & \multicolumn{9}{c}{ Treatment } & & \\
\cline { 2 - 6 } Item & Saline & EAA & BCAA- & Leu- & Lys- & SEM & $P$-value \\
\hline Glucose $(\mathrm{m} M)$ & 3.56 & 3.32 & 3.20 & 3.37 & 3.03 & 0.22 & 0.509 \\
BHBA $(\mathrm{m} M)$ & 0.42 & 0.46 & 0.74 & 0.45 & 0.56 & 0.10 & 0.269 \\
NEFA $(\mu M)$ & 86 & 83 & 93 & 106 & 75 & 9 & 0.149 \\
\hline
\end{tabular}

${ }^{1}$ Data are least squares means. Treatments were $5 \mathrm{~d}$ of abomasal infusion with saline, EAA, EAA less branchedchain amino acids (BCAA; BCAA-), EAA less Leu (Leu-), or EAA less Lys (Lys-).

suggesting that Leu was involved in regulating their utilization. Subtraction of Lys decreased Lys concentration in plasma $(P=0.001)$ but did not affect other EAA. The only NEAA affected in plasma was Tyr, a Phe-derived metabolite that was elevated on EAA and Lys - treatments $(P<0.05)$.

\section{Translational Signaling Pathways}

Mammary abundance of pS6K1 tended to increase on the Lys- treatment compared with SAL $(P=$ 0.077; Figure 1A). Total S6K1 abundance was higher with BCAA - treatment than SAL $(P=0.031)$ and tended to be higher with EAA treatment $(P=0.090)$. Phosphorylation state of S6K1 tended to be elevated by Lys - compared with SAL $(P=0.094)$.

Abundance of peIF $2 \alpha$ in mammary tissue was not affected by treatment $(P>0.293$; Figure 2A) while abundance of total eIF2 $\alpha$ increased on the EAA and Lys - treatments $(P<0.05)$ and tended to increase on Leu- $(P=0.069)$. Phosphorylation state of eIF2 $\alpha$ was not affected by treatment $(P>0.595)$.

Abundance of peIF2B $\varepsilon$ was not affected by treatment $(P>0.339$; Figure 3A) but abundance of total $\operatorname{eIF} 2 \varepsilon$ was increased by EAA infusion $(P=0.046)$ and tended to be increased by Leu - and Lys - infusions $(P$

Table 4. Plasma concentrations of amino acids in lactating dairy cows $(n=5)$ abomasally infused with EAA mixtures $^{1}$

\begin{tabular}{|c|c|c|c|c|c|c|c|}
\hline \multirow[b]{2}{*}{$\mathrm{AA}(\mu M)$} & \multicolumn{5}{|c|}{ Treatment } & \multirow[b]{2}{*}{ SEM } & \multirow[b]{2}{*}{$P$-value } \\
\hline & Saline & EAA & $\mathrm{BCAA}-$ & Leu- & Lys- & & \\
\hline Arg & $76^{\mathrm{a}}$ & $131^{\mathrm{ab}}$ & $173^{\mathrm{b}}$ & $123^{\mathrm{ab}}$ & $110^{\mathrm{ab}}$ & 19 & 0.040 \\
\hline His & $18^{\mathrm{a}}$ & $85^{\mathrm{b}}$ & $79^{\mathrm{b}}$ & $85^{\mathrm{b}}$ & $87^{\mathrm{b}}$ & 9 & $<0.001$ \\
\hline Ile & $81^{\mathrm{a}}$ & $158^{\mathrm{a}}$ & $73^{\mathrm{a}}$ & $270^{\mathrm{b}}$ & $151^{\mathrm{a}}$ & 34 & $<0.001$ \\
\hline Leu & $77^{\mathrm{a}}$ & $181^{\mathrm{b}}$ & $48^{\mathrm{a}}$ & $50^{\mathrm{a}}$ & $192^{\mathrm{b}}$ & 22 & $<0.001$ \\
\hline Val & $164^{\mathrm{a}}$ & $375^{\mathrm{b}}$ & $125^{\mathrm{a}}$ & $609^{\mathrm{c}}$ & $376^{\mathrm{b}}$ & 42 & $<0.001$ \\
\hline Lys & $66^{\mathrm{a}}$ & $203^{\mathrm{b}}$ & $174^{\mathrm{b}}$ & $161^{\mathrm{b}}$ & $56^{\mathrm{a}}$ & 20 & $<0.001$ \\
\hline Met & $20^{\mathrm{a}}$ & $84^{\mathrm{b}}$ & $75^{\mathrm{b}}$ & $65^{\mathrm{b}}$ & $78^{\mathrm{b}}$ & 8 & 0.001 \\
\hline Phe & $37^{\mathrm{a}}$ & $120^{\mathrm{b}}$ & $104^{\mathrm{b}}$ & $106^{\mathrm{b}}$ & $113^{\mathrm{b}}$ & 13 & 0.005 \\
\hline Thr & $99^{\mathrm{a}}$ & $211^{\mathrm{b}}$ & $193^{\mathrm{b}}$ & $159^{\mathrm{ab}}$ & $223^{\mathrm{b}}$ & 21 & 0.008 \\
\hline Trp & 40 & 61 & 54 & 56 & 58 & 5 & 0.070 \\
\hline Ala & 283 & 252 & 248 & 269 & 262 & 23 & 0.778 \\
\hline Asn & $36^{\mathrm{ab}}$ & $54^{\mathrm{b}}$ & $40^{\mathrm{ab}}$ & $22^{\mathrm{ab}}$ & $12^{\mathrm{a}}$ & 8 & 0.037 \\
\hline Asp & 5 & 7 & 6 & 6 & 7 & 1 & 0.079 \\
\hline Glu & 155 & 135 & 131 & 148 & 165 & 19 & 0.670 \\
\hline Gly & 374 & 321 & 262 & 296 & 381 & 63 & 0.359 \\
\hline Pro & 78 & 69 & 74 & 67 & 82 & 5 & 0.288 \\
\hline Ser & 119 & 104 & 96 & 97 & 137 & 16 & 0.090 \\
\hline Tyr & $46^{\mathrm{a}}$ & $75^{\mathrm{b}}$ & $72^{\mathrm{ab}}$ & $65^{\mathrm{ab}}$ & $88^{\mathrm{b}}$ & 6 & 0.007 \\
\hline $\mathrm{BCAA}^{2}$ & $322^{\mathrm{a}}$ & $715^{\mathrm{b}}$ & $245^{\mathrm{a}}$ & $928^{\mathrm{b}}$ & $719^{\mathrm{b}}$ & 79 & $<0.001$ \\
\hline $\mathrm{EAA}^{3}$ & $677^{\mathrm{a}}$ & $1,611^{\mathrm{c}}$ & $1,097^{\mathrm{ab}}$ & $1,683^{\mathrm{c}}$ & $1,444^{\mathrm{bc}}$ & 128 & $<0.001$ \\
\hline $\mathrm{NEAA}^{4}$ & 1,094 & 1,016 & 928 & 971 & 1,171 & 101 & 0.444 \\
\hline $\mathrm{TAA}^{5}$ & 1,781 & 2,628 & 2,025 & 2,655 & 2,581 & 227 & 0.042 \\
\hline
\end{tabular}

${ }^{\mathrm{a}-\mathrm{c}}$ Means in a row with different superscripts are significantly different, $P \leq 0.05$.

${ }^{1}$ Data are least squares means. Treatments were $5 \mathrm{~d}$ of abomasal infusion with saline, EAA, EAA less branchedchain amino acids (BCAA; BCAA-), EAA less Leu (Leu-), or EAA less Lys (Lys-).

${ }^{2} \mathrm{BCAA}=\mathrm{Ile}, \mathrm{Leu}$, and Val.

${ }^{3} \mathrm{EAA}=$ Arg, His, Ile, Leu, Lys, Met, Phe, Thr, Trp, and Val.

${ }^{4} \mathrm{NEAA}=$ nonessential amino acids; Ala, Asn, Asp, Glu, Gly, Pro, Ser, and Tyr.

${ }^{5} \mathrm{TAA}=$ total amino acids; EAA + NEAA. 
A

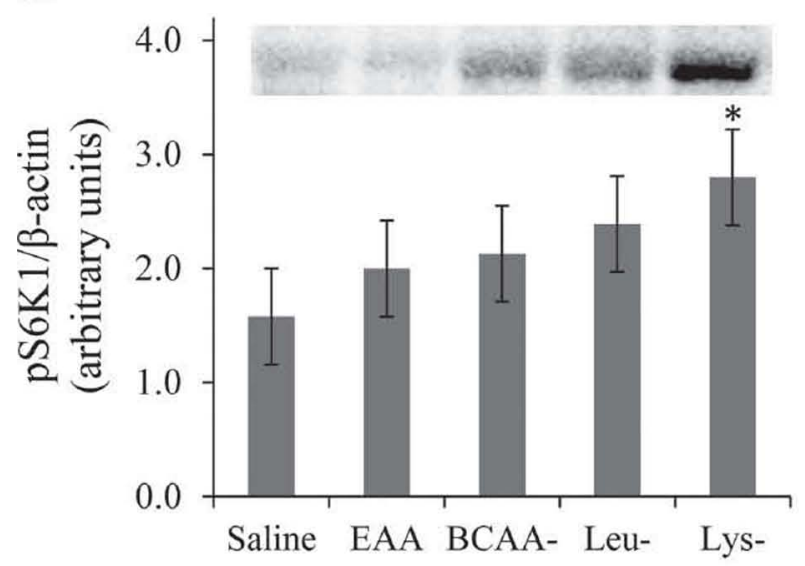

B
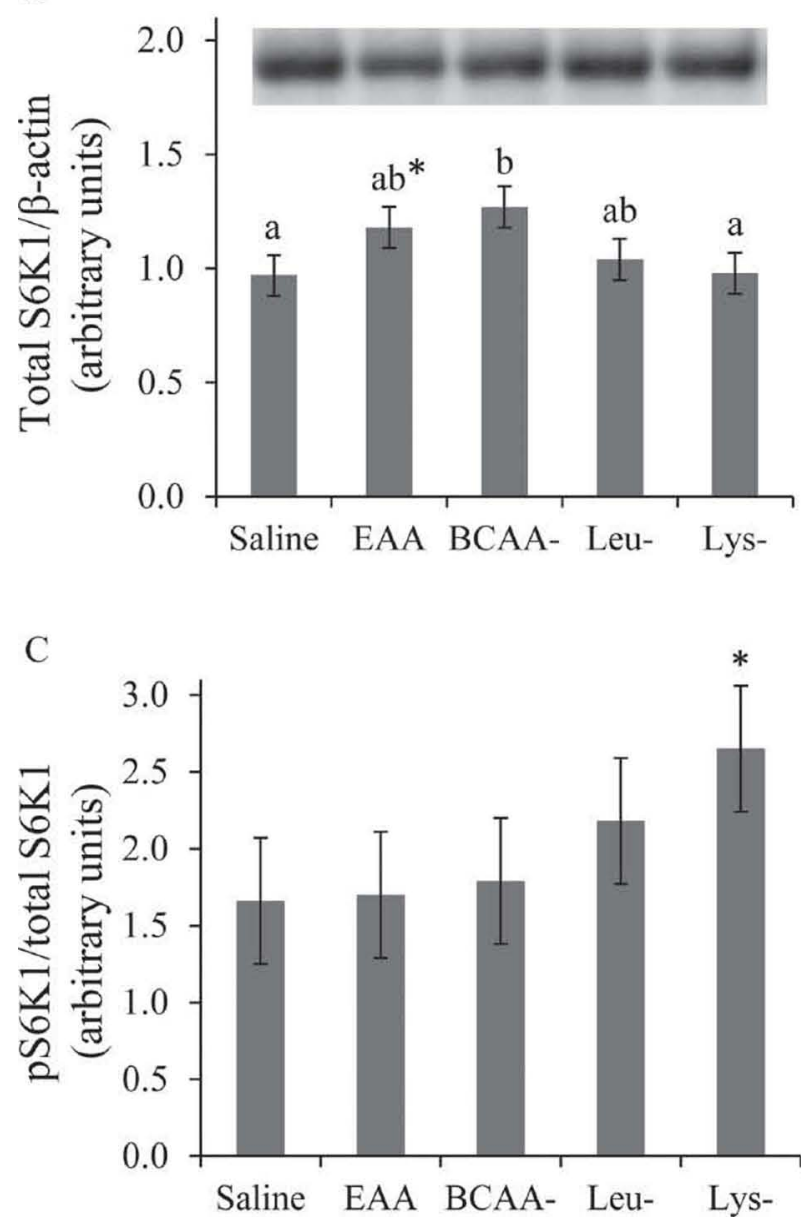

Figure 1. Abundances of phosphorylated ribosomal S6 kinase 1 normalized to $\beta$-actin (A), total ribosomal S6 kinase 1 (S6K1) normalized to $\beta$-actin (B), and phosphorylated S6K1 normalized to total S6K1 (C) in mammary tissue of lactating dairy cows $(\mathrm{n}=5)$ after $5 \mathrm{~d}$ of abomasal infusion with saline, EAA, EAA less branched-chain AA (BCAA-), EAA less Leu (Leu-), or EAA less Lys (Lys-). Values are presented as means \pm SE. Means without a common letter differ, $P \leq 0.05$. ${ }^{*}$ Indicates tendency to be different from control $(0.05<P$ $<0.10)$.
A

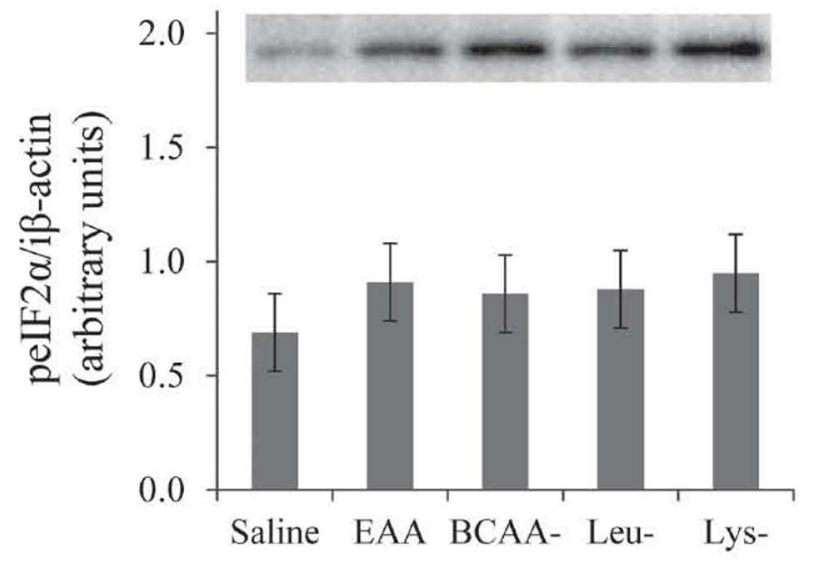

B
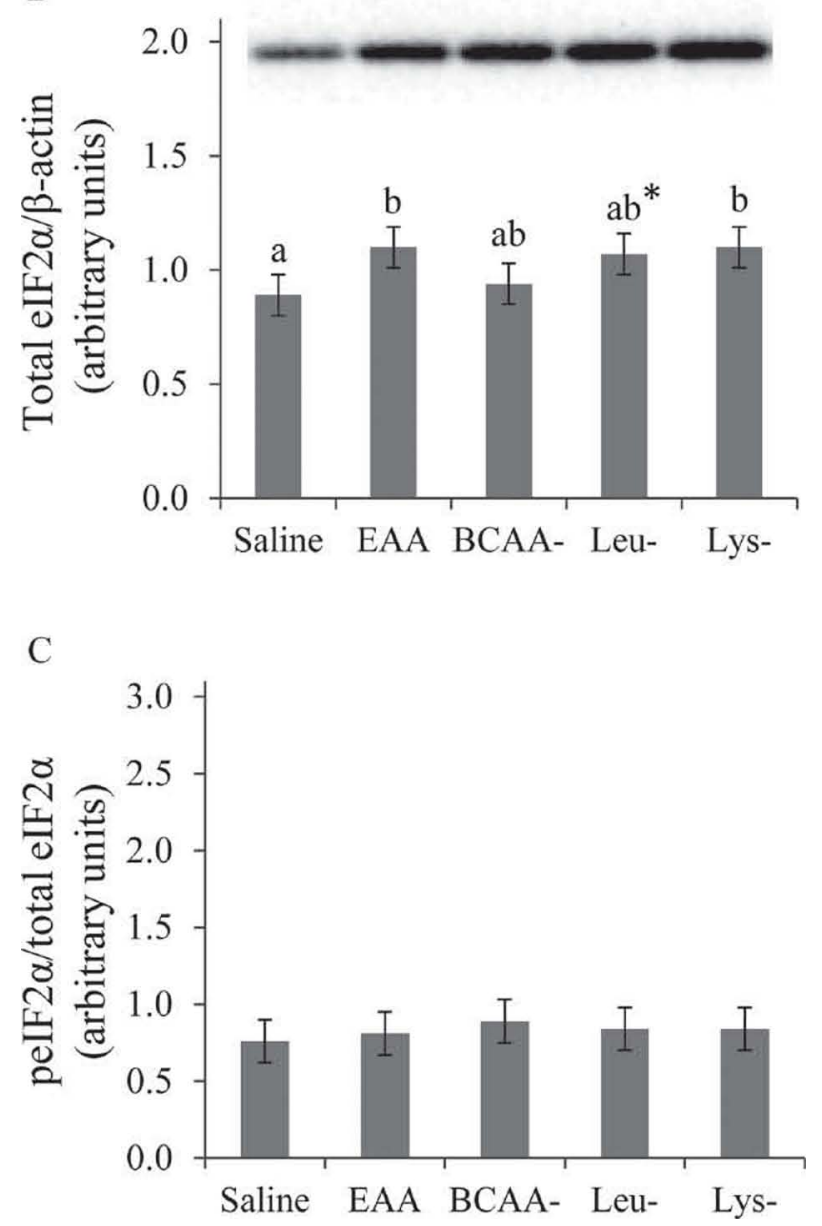

Figure 2. Abundances of phosphorylated eukaryotic initiation factor $2 \alpha$ normalized to $\beta$-actin (A), total eukaryotic initiation factor $2 \alpha$ $(\mathrm{eIF} 2 \alpha)$ normalized to $\beta$-actin (B), and phosphorylated eIF $2 \alpha$ normalized to total eIF $2 \alpha(\mathrm{C})$ in mammary tissue of lactating dairy cows $(\mathrm{n}=5)$ after $5 \mathrm{~d}$ of abomasal infusion with saline, EAA, EAA less branched-chain AA (BCAA-), EAA less Leu (Leu-), or EAA less Lys (Lys-). Values are presented as means \pm SE. Means without a common letter differ, $P \leq 0.05$. *Indicates tendency to be different from control $(0.05<P<0.10)$. 
$<0.078)$. Phosphorylation state of eIF2B $\varepsilon$ tended to decrease with EAA and Lys - treatments $(P<0.10)$.

\section{DISCUSSION}

To address the effects of group II EAA deficiencies and imbalances on milk production and molecular signaling pathways in the mammary glands, lactating dairy cattle were fed a diet low in protein and infused via the abomasum with EAA mixtures. Duodenal flows of MP from the diet were estimated, using NRC (2001), to be $912 \mathrm{~g} / \mathrm{d}$ on average and 1,475 g/d including the EAA infusate $(563 \mathrm{~g} / \mathrm{d})$. Estimated duodenal supplies of BCAA, Leu, and Lys from the diet were 403, 185, and $134 \mathrm{~g} / \mathrm{d}$, respectively. The EAA infusate provided $38 \%$ of the total duodenal flow, whereas subtractions removed 35,34 , and $42 \%$ of the duodenal BCAA, Leu, and Lys supplies, respectively.

Supplementation of $563 \mathrm{~g}$ of all 10 EAA resulted in a significant increase in milk protein yield that was negated by removing Lys, or Leu, or all 3 BCAA. Although Lys subtraction from an EAA infusate has previously been shown to decrease milk protein yield (Fraser et al., 1991; Weekes et al., 2006; Lapierre et al., 2009), Weekes et al. (2006) found no difference in milk component yields due to BCAA subtraction. They subtracted $160 \mathrm{~g} / \mathrm{d}$ of BCAA from a total supply of 411 $\mathrm{g} / \mathrm{d}$ of metabolizable BCAA, whereas in our experiment, $215 \mathrm{~g} / \mathrm{d}$ of BCAA was subtracted from a total supply of $618 \mathrm{~g} / \mathrm{d}$. This larger subtraction caused Leu concentration in plasma to decrease to $48 \mu M$, compared with a less severe reduction to $63 \mu M$ in the experiment of Weekes et al. (2006). When Rulquin and Pisulewski (2006) depressed milk protein yield by Leu subtraction, the concentration of Leu in plasma decreased from 107 to $42 \mu M$, whereas Ile and Val increased from 94 to 167 and from 184 to $300 \mu M$, respectively. Similarly, Leu subtraction in the current experiment produced a plasma Leu concentration of $50 \mu M$ and a milk protein depression of $212 \mathrm{~g} / \mathrm{d}$. Plasma Ile and Val also increased in response to Leu subtraction, suggesting that Leu was involved in regulating their utilization or entry into circulation. Reducing plasma Val concentration from 137 to $66 \mu M$ by Val subtraction depressed milk protein yield, whereas Ile concentrations as low as $45 \mu M$ during Ile subtraction did not affect milk protein yield (Haque et al., 2013). Because plasma Val and Ile concentrations during BCAA- infusion were 125 and $73 \mu M$, respectively - well above the milk protein-depressing concentrations - we conclude that Leu concentrations $\leq 50 \mu M$ were responsible for the decrease in milk protein yield on BCAA-.

Cellular mechanisms by which EAA influence daily milk protein yields of mammary glands in vivo have
A

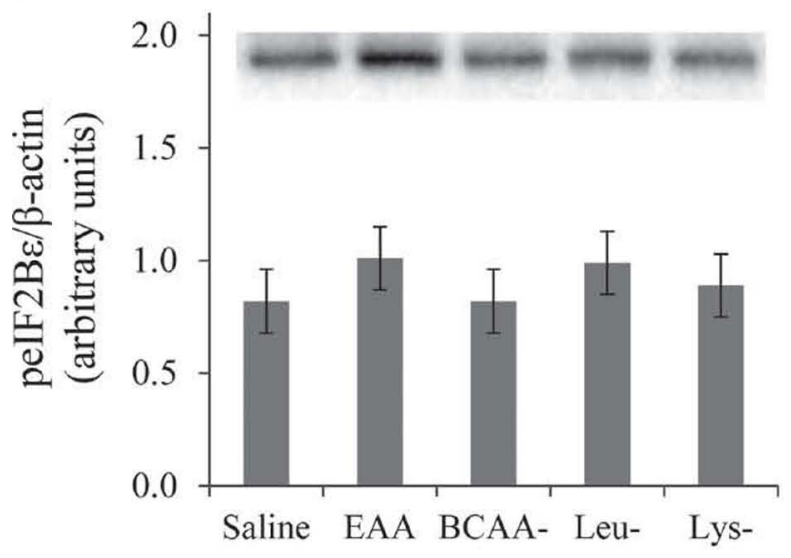

B

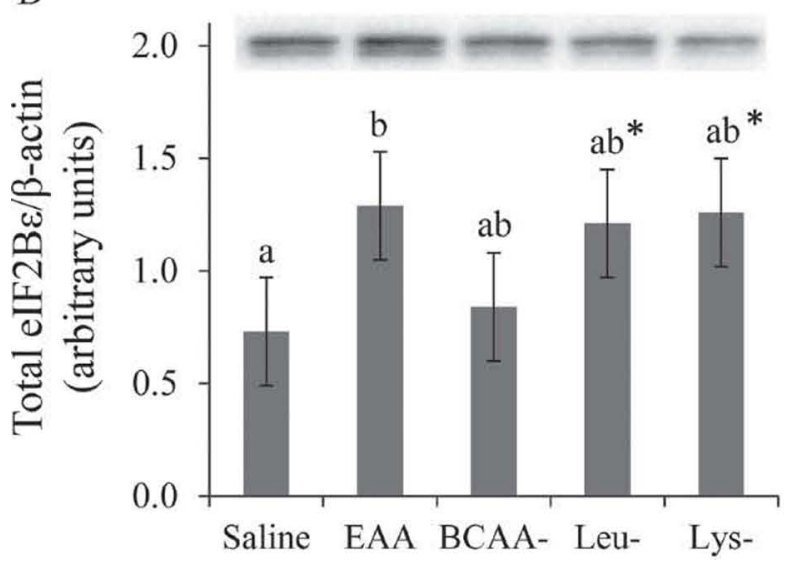

$\mathrm{C}$

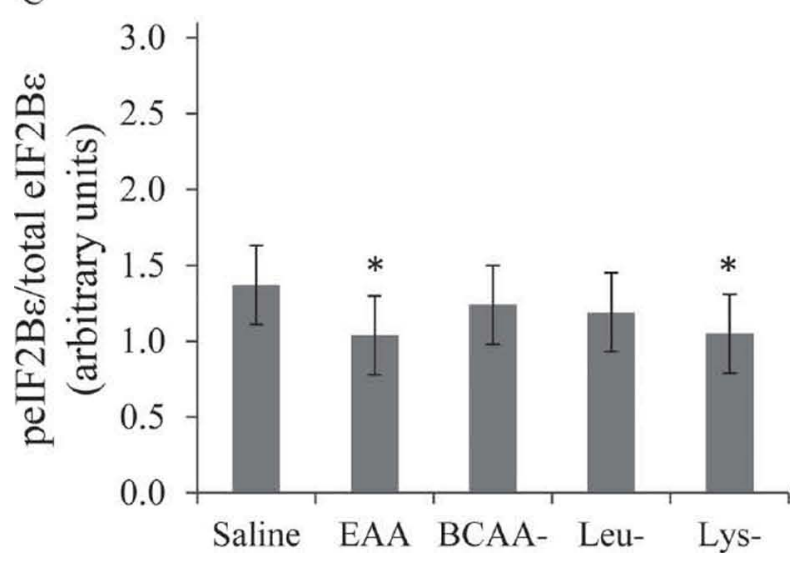

Figure 3. Abundances of phosphorylated eukaryotic initiation factor $2 \mathrm{~B} \varepsilon$ normalized to $\beta$-actin $(\mathrm{A})$, total eukaryotic initiation factor $2 \mathrm{~B} \varepsilon(\mathrm{eIF} 2 \mathrm{~B} \varepsilon)$ normalized to $\beta$-actin $(\mathrm{B})$, and phosphorylated eIF2B $\varepsilon$ normalized to total $\mathrm{eIF} 2 \mathrm{~B} \varepsilon(\mathrm{C})$ in mammary tissue of lactating dairy cows $(\mathrm{n}=5)$ after $5 \mathrm{~d}$ of abomasal infusion with saline, EAA, EAA less branched-chain AA (BCAA-), EAA less Leu (Leu-), or EAA less Lys (Lys-). Values are presented as means \pm SE. Means without a common letter differ, $P<0.05$. *Indicates tendency to be different from control $(0.05<P<0.10)$. 
not been identified. The networks of signaling proteins that control mRNA translation in eukaryotic cells via $\mathrm{S} 6 \mathrm{~K} 1$, eIF2B $\varepsilon$, and eIF2 $\alpha$ phosphorylation are promising candidates for study because (1) they integrate the same extracellular hormonal stimuli and intracellular AA and ATP concentrations that appear to affect milk protein yields (Proud, 2005; Gwinn et al., 2008; Shimobayashi and Hall, 2014), (2) they have been shown to be responsive to these stimuli in mammary epithelial cells in culture (Moshel et al., 2006; Burgos and Cant, 2010; Appuhamy et al., 2012; Burgos et al., 2013), and (3) they are responsible for effects of a meal, exercise, and various stressors on protein synthesis in liver and muscle of nonruminants (Kimball et al., 2000; Karinch et al., 2008; Hulmi et al., 2009; Sikalidis and Stipanuk, 2010). Our previous experiment with balanced and imbalanced EAA infusions showed that both types of infusate increased abundance of mTORC1phosphorylated S6K1 (Doelman et al., 2015). In the current experiment, Lys- infusion tended to increase pS6K1 abundance, similar to our previous finding, but the other AA infusions did not. Instead, abundance of total S6K1 was elevated with EAA and BCAA- infusions. This increased abundance lies in contrast to the decreased S6K1 abundance noted in response to infusion of EAA mixtures lacking the group I EAA His, Met, Phe, or Trp (Doelman et al., 2015). Because a change in phosphorylation state occurs within minutes to produce short-term changes in protein synthesis after a meal (Davis et al., 2000; Kimball et al., 2000), the total abundance of signaling proteins in addition to their phosphorylation state may be important to consider when protein synthesis is altered through longterm dietary treatment (Lynch et al., 2002; Curtis et al., 2014; Doelman et al., 2015). The S6K1 protein is involved in regulating many cellular processes beyond mRNA translation such as cell proliferation, apoptosis, and insulin signaling (Magnuson et al., 2012). Regulation of S6K1 expression has not been well characterized so it is difficult to speculate as to the cause of changes in its protein abundance. Because the apoptotic peptidase caspase-3 degrades S6K1 (Piedfer et al., 2013), inhibition of mammary apoptosis as part of a growth response to EAA may increase S6K1 abundance, as we observed in mammary tissue. In any case, upregulation of mammary S6K1 expression by EAA and BCAA - is potentially stimulatory to protein synthesis.

Compared with $\mathrm{SAL}$, total $\mathrm{eIF} 2 \mathrm{~B} \varepsilon$ abundances were higher on all AA treatments except BCAA-. This upregulation was observed previously with complete and imbalanced EAA infusions (Doelman et al., 2015) and, due to a correlation between S6K1 phosphorylation state and $\mathrm{eIF} 2 \mathrm{~B} \varepsilon$ abundance, the suggestion was put forward that mTORC1 activation may have stimulated
$\mathrm{eIF} 2 \mathrm{~B} \varepsilon$ translation as shown for skeletal muscle (Kubica et al., 2008). The correlation coefficient between S6K1 phosphorylation state and $\mathrm{eIF} 2 \mathrm{~B} \varepsilon$ abundance in the current experiment was $0.62(P=0.013)$, which again suggests a possible deterministic relationship. Guanine nucleotide exchange on eIF2 is carried out by eIF2B as part of the cycle that delivers the initiator Met-tRNA to the ribosome (Proud, 2005). Activity of eIF2B is inhibited by glycogen synthase kinase 3 -mediated phosphorylation of the $\varepsilon$ subunit on $\operatorname{Ser}^{539}$, and by competitive binding of phosphorylated eIF2. Phosphorylation of eIF $2 \mathrm{~B} \varepsilon$ on Ser $^{539}$ tended to be reduced by EAA and Lys - infusions, which, together with the higher total abundance of $\operatorname{eIF} 2 \mathrm{~B} \varepsilon$, is stimulatory to eIF2 recycling and protein synthesis. Abundance of peIF $2 \alpha$ was not affected by treatment but abundance of total eIF $2 \alpha$ was higher on all AA infusions except BCAA-. Again, this effect is potentially stimulatory to protein synthesis due to a greater amount of eIF2 available to participate in initiation of mRNA translation. Kimball et al. (1992) found that differences in protein synthesis rates between tissues of rats at different ages were highly related to their eIF2 content. Mechanisms by which eIF2 expression is regulated have been studied little but a sepsisinduced increase in hepatic eIF $2 \alpha$ abundance was due to a higher proportion of eIF $2 \alpha$ mRNA in polysomes, rather than an increase in eIF2 $\alpha$ mRNA expression (Vary et al., 1994). Although we are unaware of any studies investigating the role of $\mathrm{mTORC} 1$ in regulation of eIF $2 \alpha$ translation particularly, the correlation coefficient between mammary S6K1 phosphorylation state and eIF $2 \alpha$ abundance in the current study was $0.58(P$ $=0.007$ ).

The EAA, Leu-, and Lys- treatments increased $\mathrm{eIF} 2 \mathrm{~B} \varepsilon$ and $\mathrm{eIF} 2 \alpha$ abundances, whereas BCAA - was the only AA infusion that did not. Infusion of EAA mixtures lacking single group I EAA also upregulated mammary eIF2B $\varepsilon$ abundances (Doelman et al., 2015). Apparently, then, compared with other EAA imbalances, or balanced EAA mixtures, a BCAA imbalance brings about a different response in mammary eIF2B $\varepsilon$ and eIF $2 \alpha$. A unique aspect of the BCAA imbalance, compared with all other AA infusions, was a lack of increase in Ile and Val concentrations in plasma. Leucine is a highly potent stimulator of mTORC1 in muscle, liver, and mammary cells (Anthony et al., 2000; Moshel et al., 2006; Toerien et al., 2010; Appuhamy et al., 2012; Suryawan et al., 2012) and might be expected to be responsible for some of the difference in mammary translational responses between BCAA subtractions and other EAA subtractions. However, plasma Leu concentrations were not different between Leu- and BCAA - treatments, whereas eIF2B $\varepsilon$ and eIF $2 \alpha$ abundances increased on the former treatment and not on 
the latter. Isoleucine has been shown to be nearly as potent as Leu at stimulating mammary mTORC1 in vitro (Appuhamy et al., 2012; Arriola-Apelo et al., 2014) so the increase in plasma Ile during Leu- infusion may have compensated for the low plasma Leu concentration and allowed eIF2B $\varepsilon$ and eIF $2 \alpha$ abundances to increase. Our findings suggest that a deficiency of all 3 BCAA may have impaired milk protein yield by deactivation of mTORC1-mediated upregulation of eIF2B $\varepsilon$ and eIF $2 \alpha$ abundances.

Despite increases in mammary $\operatorname{eIF} 2 \mathrm{~B} \varepsilon$ and $\mathrm{eIF} 2 \alpha$ abundances on the Leu- and Lys- treatments, milk protein yields were not stimulated compared with SAL. Low concentrations of EAA may be thought to limit rates of protein synthesis by the mass-action effect of a substrate on the rate of a chemical reaction. However, the mass-action effect of amino acids is on transfer ( $t$ ) RNA charging and, subsequently, elongation of the nascent polypeptide chain. Elongation does not affect the rate of protein synthesis unless initiation is somehow affected. The purported mechanism by which single EAA deficiencies inhibit protein synthesis in eukaryotic cells is via phosphorylation of eIF $2 \alpha$ on Ser $^{51}$ initiated by free tRNA (Proud, 2005). When rats were fed a diet $30 \%$ deficient in Met + Cys for $7 \mathrm{~d}$, BW gain was reduced and phosphorylation state of eIF $2 \alpha$ in liver was elevated (Sikalidis and Stipanuk, 2010). However, in myoblasts from quail, Met deprivation did not affect peIF2 $\alpha$ (Métayer-Coustard et al., 2010). We found no effect of any of the complete or imbalanced EAA infusions on phosphorylation state of eIF $2 \alpha$. Similarly, group I EAA deficiencies had no effect on mammary peIF $2 \alpha$ (Doelman et al., 2015). Phosphorylation of eIF $2 \alpha$ does not appear to be the mechanism by which EAA deficiencies impair milk protein production. Low concentrations of non-BCAA in circulation interfere with milk protein synthesis in the mammary glands of lactating cows by a mechanism that has yet to be identified.

\section{CONCLUSIONS}

Milk protein yield of cows on a low-MP diet was responsive to EAA supply, as indicated by the increase in milk protein yield induced by abomasal infusion of $563 \mathrm{~g} / \mathrm{d}$ of a mix of all 10 EAA. Deficiencies of group II EAA were created by subtracting all 3 BCAA, Leu, or Lys from the EAA infusate, which caused milk protein yields to decrease to the control level in each case. Branched-chain AA deficiencies were associated with plasma Leu concentrations $\leq 50 \mu M$. The only 5-d AA infusion that stimulated mammary mTORC1 compared with SAL was Lys-. All of the AA infusions except BCAA - upregulated mammary eIF2B $\varepsilon$ and eIF $2 \alpha$ abundances. The translational signaling network is being studied in mammary tissue in an attempt to understand how the mammary glands set a rate of milk protein production appropriate to the level of EAA supply. Branched-chain AA deficiencies may impair milk protein yields through deactivation of mTOR-mediated upregulation of eIF2B $\varepsilon$ and eIF $2 \alpha$ abundances. Deficiencies of Leu and Lys did not affect $\mathrm{eIF} 2 \mathrm{~B} \varepsilon$ and $\mathrm{eIF} 2 \alpha$ abundances but milk protein yields declined, indicating that other factors were responsible for controlling protein yield. Identification of the factors that mediate effects of EAA deficiencies on milk protein yield will aid in efforts to improve the efficiency of milk protein production and environmental impact of dairying.

\section{ACKNOWLEDGMENTS}

The authors gratefully acknowledge the barn staff at the Burford Research Facility and the skilled technical assistance of Kelly Nichols, Linaya Pot, and Ryan Laforest (University of Guelph, Guelph, ON, Canada). Financial support was provided by Nutreco Canada Inc. (Guelph, ON, Canada) and NSERC Canada (Ottawa, ON, Canada).

\section{REFERENCES}

Anthony, J. C., F. Yoshizawa, T. G. Anthony, T. C. Vary, L. S. Jefferson, and S. R. Kimball. 2000. Leucine stimulates translation initiation in skeletal muscle of postabsorptive rats via a rapamycinsensitive pathway. J. Nutr. 130:2413-2419.

Appuhamy, J. A. D. R. N., N. A. Knoebel, W. A. D. Nayananjalie, J. Escobar, and M. D. Hanigan. 2012. Isoleucine and leucine independently regulate mTOR signalling and protein synthesis in MAC-T cells and bovine mammary tissue slices. J. Nutr. 142:484-491.

Arriola Apelo, S. I., L. M. Singer, X. Y. Lin, M. L. McGilliard, N. R. St-Pierre, and M. D. Hanigan. 2014. Isoleucine, leucine, methionine, and threonine effects on mammalian target of rapamycin signaling in mammary tissue. J. Dairy Sci. 97:1047-1056.

Bequette, B. J., M. D. Hanigan, A. G. Calder, C. K. Reynolds, G. E. Lobley, and J. C. MacRae. 2000. Amino acid exchange by the mammary gland of lactating goats when histidine limits milk production. J. Dairy Sci. 83:765-775.

Boogers, I., W. Plugge, Y. Q. Stokkermans, and A. L. L. Duchateau. 2008. Ultra-performance liquid chromatographic analysis of amino acids in protein hydrolysates using an automated pre-column derivitization method. J. Chromatogr. A 1189:406-409.

Burgos, S. A., and J. P. Cant. 2010. IGF-1 stimulates protein synthesis by enhanced signaling through mTORC1 in bovine mammary epithelial cells. Domest. Anim. Endocrinol. 38:211-221.

Burgos, S. A., J. J. M. Kim, M. Dai, and J. P. Cant. 2013. Energy depletion of bovine mammary epithelial cells activates AMPK and suppresses protein synthesis through inhibition of mTORC1 signaling. Horm. Metab. Res. 45:183-189.

Canadian Council on Animal Care. 2009. Guidelines on: the care and use of farm animals in research, teaching and testing. Canadian Council on Animal Care, Ottawa, ON, Canada.

Curtis, R. V., J. J. M. Kim, D. L. Bajramaj, J. Doelman, V. R. Osborne, and J. P. Cant. 2014. Decline in mammary translational capacity during intravenous glucose infusion into lactating dairy cows. J. Dairy Sci. 97:430-438. 
Davis, T. A., H. V. Nguyen, A. Suryawan, J. A. Bush, L. S. Jefferson, and S. R. Kimball. 2000. Developmental changes in the feeding induced stimulation of translation initiation in muscle of neonatal pigs. Am. J. Physiol. Endocrinol. Metab. 279:E1226-E1234.

Doelman, J., R. V. Curtis, M. Carson, J. J. M. Kim, J. A. Metcalf, and J. P. Cant. 2015. Essential amino acid infusions stimulate mammary expression of eukaryotic initiation factor $2 \mathrm{~B} \varepsilon$ but milk protein yield is not increased during an imbalance. J. Dairy Sci. 98:4499-4508.

Doepel, L., and H. Lapierre. 2011. Deletion of arginine from an abomasal infusion of amino acids does not decrease milk protein yield in Holstein cows. J. Dairy Sci. 94:864-873.

Fraser, D. L., E. R. Ørskov, F. G. Whitelaw, and M. F. Franklin. 1991. Limiting amino acids in dairy cows given casein as the sole source of protein. Livest. Prod. Sci. 28:235-252.

Gwinn, D. M., D. B. Shackelford, D. F. Egan, M. M. Mihaylova, A. Mery, D. S. Vasquez, B. E. Turk, and R. J. Shaw. 2008. AMPK phosphorylation of raptor mediates a metabolic checkpoint. Mol. Cell 30:214-226.

Haque, M. N., H. Rulquin, and S. Lemosquet. 2013. Milk protein responses in dairy cows to changes in postruminal supplies of arginine, isoleucine, and valine. J. Dairy Sci. 96:420-430.

Hulmi, J. J., J. Tannerstedt, S. Harri, H. Kainulainen, V. Kovanen, and A. A. Mero. 2009. Resistance exercise with whey protein injestion affects mTOR signaling pathway and myostatin in men. J. Appl. Physiol. 106:1720-1729.

Karinch, A. M., J. H. Martin, and T. C. Vary. 2008. Acute and chronic ethanol consumption differentially impact pathways limiting hepatic protein synthesis. Am. J. Physiol. Endocrinol. Metab. 295:E3-E9.

Kim, C.-H., J.-J. Choung, and D. G. Chamberlain. 1999. Determination of the first-limiting amino acid for milk production in dairy cows consuming a diet of grass silage and a cereal based supplement containing feather meal. J. Sci. Food Agric. 79:1703-1708.

Kimball, S. R., L. S. Jefferson, H. V. Nguyen, A. Suryawan, J. A. Bush, and T. A. Davis. 2000. Feeding stimulates protein synthesis in muscle and liver of neonatal pigs through an mTOR-dependent process. Am. J. Physiol. Endocrinol. Metab. 279:E1080-E1087.

Kimball, S. R., T. C. Vary, and L. S. Jefferson. 1992. Age-dependent decrease in the amount of eukaryotic initiation factor 2 in various rat tissues. Biochem. J. 286:263-268.

Kubica, N., J. L. Crispino, J. W. Gallagher, S. R. Kimball, and L. S. Jefferson. 2008. Activation of the mammalian target of rapamycin complex 1 is both necessary and sufficient to stimulate eukaryotic initiation factor $2 \mathrm{~B} \varepsilon \mathrm{mRNA}$ translation and protein synthesis. Int. J. Biochem. Cell Biol. 40:2522-2533.

Lapierre, H., L. Doepel, E. Milne, and G. E. Lobley. 2009. Responses in mammary and splanchnic metabolism to altered lysine supply in dairy cows. Animal 3:360-371.

Lynch, C. J., S. M. Hutson, B. J. Patson, A. Vaval, and T. C. Vary. 2002. Tissue-specific effects of chronic dietary leucine and norleucine supplementation on protein synthesis in rats. Am. J. Physiol. Endocrinol. Metab. 283:E824-E835.

Magnuson, B., B. Ekim, and D. C. Fingar. 2012. Regulation and function of ribosomal protein $\mathrm{S} 6$ kinase (S6K) within mTOR signalling networks. Biochem. J. 441:1-21.

Mepham, T. B. 1982. Amino acid utilization by lactating mammary gland. J. Dairy Sci. 65:287-298.

Métayer-Coustard, S., H. Mameri, I. Seiliez, S. Crochet, P. Crépieux, Y. Mercier, P. E. Geraert, and S. Tesseraud. 2010. Methionine deprivation regulates the S6K1 pathway and protein synthesis in avian QM7 myoblasts without activating the GCN2/eIF2 $\alpha$ cascade. J. Nutr. 140:1539-1545.

Metcalf, J. A., L. A. Crompton, D. Wray-Cahen, M. A. Lomax, J. D. Sutton, D. E. Beever, J. C. MacRae, B. J. Bequette, F. R. C. Backwell, and G. E. Lobley. 1996. Responses to milk constituents to intravascular administration of two mixtures of amino acids to dairy cows. J. Dairy Sci. 79:1425-1429.

Moshel, Y., R. E. Rhoads, and I. Barash. 2006. Role of amino acids in translational mechanisms governing milk protein synthesis in murine and ruminant mammary epithelial cells. J. Cell. Biochem. $98: 685-700$

NRC. 2001. Nutrient Requirements of Dairy Cattle. 7th rev. ed. National Academies Press, Washington, DC.

Piedfer, M., S. Bouchet, R. Tang, C. Billard, D. Dauzonne, and B. Bauvois. 2013. p70S6 kinase is a target of the novel proteasome inhibitor 3,3'-diamino-4'-methoxyflavone during apoptosis in human myeloid tumor cells. Biochim. Biophys. Acta 1833:1316-1328.

Proud, C. G. 2005. eIF2 and the control of cell physiology. Semin. Cell Dev. Biol. 16:3-12.

Robinson. P. H. 2010. Impacts of manipulating ration metabolizable lysine and methionine levels on the performance of lactating dairy cows: A systematic review of the literature. Livest. Sci. 127:115126

Rulquin, H., and P. M. Pisulewski. 2006. Effects of graded levels of duodenal leucine on mammary uptake and output in lactating dairy cows. J. Dairy Res. 73:328-339.

Schwab, C. G., L. D. Satter, and A. B. Clay. 1976. Response of lactating cows to abomasal infusion of amino acids. J. Dairy Sci. $59: 1254-1270$

Shimobayashi, M., and M. N. Hall. 2014. Making new contacts: The mTOR network in metabolism and signalling crosstalk. Nat. Rev. Mol. Cell Biol. 15:155-162.

Sikalidis, A. K., and M. H. Stipanuk. 2010. Growing rats respond to a sulfur amino acid-deficient diet by phosphorylation of the $\alpha$ subunit of eukaryotic initiation factor 2 heterotrimeric complex and induction of adaptive components of the integrated stress response. J. Nutr. 140:1080-1085.

Storm, E., and E. R. Ørskov. 1984. The nutritive value and rumen micro-organisms in ruminants. 4. The limiting amino acids of microbial protein in growing sheep determined by a new approach. Br. J. Nutr. 52:613-620.

Suryawan, A., R. M. Torrazza, M. C. Gazzaneo, R. A. Orellana, M. L. Fiorotti, S. W. El-Kadi, N. Srivastava, H. V. Nguyen, and T. A. Davis. 2012. Enteral leucine supplementation increases protein synthesis in skeletal and cardiac muscles and visceral tissues of neonatal pigs through mTORC 1-dependent pathways. Pediatr. Res. 71:324-331.

Toerien, C. A., D. R. Trout, and J. P. Cant. 2010. Nutritional stimulation of milk protein yield of cows is associated with changes in phosphorylation of mammary eukaryotic initiation factor 2 and ribosomal S6 kinase 1. J. Nutr. 140:285-292.

Vanhatalo, A., P. Huhtanen, V. Toivonen, and T. Varvikko. 1999. Response of dairy cows fed grass silage diets to abomasal infusions of histidine alone or in combinations with methionine and lysine. J. Dairy Sci. 82:2674-2685.

Vary, T. C., C. V. Jurasinski, A. M. Karinch, and S. R. Kimball. 1994. Regulation of eukaryotic initiation factor-2 expression during sepsis. Am. J. Physiol. 266:E193-E201.

Weekes, T. L., P. H. Luimes, and J. P. Cant. 2006. Responses to amino acid imbalances and deficiencies in lactating dairy cows. J. Dairy Sci. 89:2177-2187. 